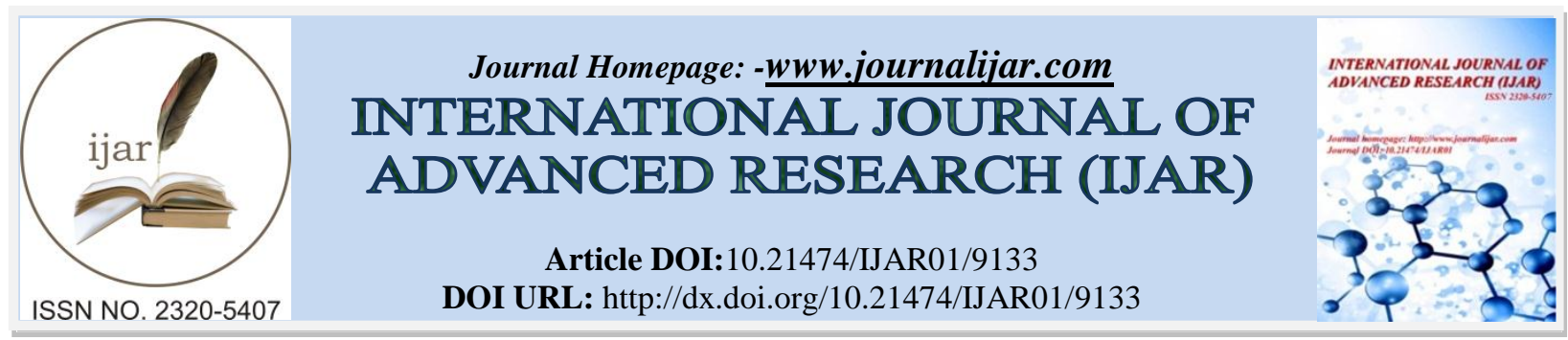

RESEARCH ARTICLE

\title{
ALTERNATIVE POLICY FOR RESOLVING NATIONAL BORDER PROBLEMS BETWEEN THE GOVERNMENT OF INDONESIA AND TIMOR LESTE VIEWED FROM ASPECTS CULTURE.
}

Hugo Lourenço da Costa.

Public Administration Study Program Graduate program Nusa Cendana University, Kupang.

\section{Manuscript Info}

\section{Manuscript History}

Received: 24 March 2019

Final Accepted: 26 April 2019

Published: May 2019

Key words:-

Policy, Conflict, Culture, Local Wisdom.

\section{Abstract}

Relationship and cultural closeness between people two countries politically different, but it blends together culture, customs, traditions, languages and others as one nation family. This is what is seen from the Ambeno community in Timor Leste and Amfoang (NTT) in Indonesia which then conflicts because of the determination of the boundary which has not been resolved by two countries. Actually there is value customary values and very strong culture that binds the people of two countries. Factor that caused the conflict to be triggered by the release and establishment of East Timor as a new country and interests of certain groups who do not want estability on the border.Various theories and alternative approaches namely pen cultural approach used as an analysis knife so it is believed to be able to provide the best solution for settlement dispute over the Naktuka border area. Conflict theory and policy and variety Approach politics, administration and culture has important for three core values local wisdom towards settlement of this case, namely; Nahebiti boots, but bandu and cruzjovem. Qualitative methodology with descriptive nature of analysis with a case and approach policy assessment and collection techniques the data is done by doing it interview and observation. Data testing is done by using data validity qualitative. The results of the study show that by using a cultural approach provide enormous benefits for both $n$ state so the settlement model this border conflict will be a model for the country other countries that have cases the same about border conflict. Value local cultural values or local wisdom that is, Tara bandu, Cruz Jovem and NaheBiti Boot globally and global cultural values acceptable to local culture. Local wisdom will be a model for settlement stopped and conflicts between countries in relations international.

Copy Right, IJAR, 2019,. All rights reserved.

\section{Introduction:-}

Ambeno is one of the Kingdoms in West Timor. The kingdom was formed in conjunction with the kingdom of Amfoang after the kingdom of Wehali developed the region his power to West Timor was under the leadership of LiuraiSonbai. In the colonial era, while the Ambenu kingdom was under Portuguese control, and the kingdom of Amfoang was located under Dutch rule. After Indonesia's independence, the kingdom of Amfoang entered inside the

Corresponding Author:-Hugo Lourenço da Costa.

Address:-Public Administration Study Program Graduate program Nusa Cendana University, 
territory of the Republic of Indonesia, while the Ambenu kingdom remained in the colony Portuguese. In the era of integration, the Ambenu kingdom became one of the districts of the province of East Timor. Furthermore, when the province of East Timor broke away from the NKRI in 1999 and formed RDTL, Ambenu became one of the districts of RDTL. Because of political separation, the kingdom threatening Amfoang threatened war with Timor Leste (compas.com, Friday 1206 2009). Border problems between RI and RDTL in the Ambenu enclave until now still in progress. In Kupang regency resolved segment is located at Iron Noel / Citrana. The location of the dispute is located in the Amfoan sub-district. After Timor the East is now called the Democratic Republic of East Timor (RDTL), breaking away from the Unitary State of the Republic of Indonesia through a process of polling the opinion facilitated by the United Nations in 1999 was not necessarily the end from a conflict or problem. Various challenges and problems even new problems surfaced. Problems of boundary lines between the two countries along the border landline of both countries, and several other problems such as "Illegal crossing" people and item seb or an illustration or illustration for the people of the two countries in particular communities around the border, political elites at both national and global levels. The factor that became the main focus of study between the two governments, namely the government Indonesia and the Timor Leste government on the issue of TAPAL LIMITS IN ADVANCE the area or scenery behind the main object of contemplation, especially when perceived as a framework for it. The house stands against a background of sheltering trees sinonim: backdrop backcloth surrounding(s) setting scene the circumstances or situation prevailing at a particular time or underlying a particular event. The political and economic background sinonim: circumstances context conditions situation environment milieu scene scenario Sinonim background nomina backdrop social circumstances experience circumstances setting desktop backcloth background knowledge ground backdrop backcloth surrounding(s) setting scene social circumstances family circumstances environment class culture tradition upbringing experience record history past training education grounding knowledge backstory circumstances context conditions situation environment milieu scene scenario setting scope (EOCUSSE) which always raises border problems or conflicts. The conflict often triggering disputes between the people of the two countries that inhabit the region the border is mas the Naktuka community of Oecusse district which is part of RDTL and the Oepoli community, in NTT which is part of the NKRI. Anderson, (1972:

7) in his observations, said that the nation is a imaginable political community (imagined polytical community) in that area clear boundary and sovereign. So even though the nation is a commu politics like the diba it must have clear boundaries. The boundary clarity of this area is territorial sovereignty within the power of a sovereign country. Next is Mac Iver, in his book Basic The foundation of Miriam's Political Science Budiardjo, (2002: 46) says that the state is a withdrawal or offering who acted through a law that was realized by the government territorial equipped enforce conditions general birth conditions of social order. In with a power to coerce in life which is limited by location there it says that the formation of a country includes elements element; the existence of the existence of territory, the existence of a sovereign government and recognition from other countries. Several things interesting from the conflict between to two people at the Naktuka border itself, among others; First, Communities from the two regions are mutually exclusiveclaim claim land disputes as ancestral land so that there is a feeling that each each has the same rights over the disputed land. Second from the historical perspective of Naktuka at the time of integration to the NKRI the people in the area were not conflict, third, this conflict arose when Oecusse people fled to NTT, especially in Oepoli, which keeps trying or trying to get rights to the area Naktuka, fourth, that the Naktuka area is extensive agricultural land as well have a large enough water source. Naktuka'sproblems aside from conflicts between the two countries in the region borders, but it remains a political responsibility for both countries, namely the government. The Unitary State of the Republic of Indonesia on the one hand and the government of the Democratic Republic Timor Lesta on the other side. At present the governments of the two countries are still holding back and very careful in taking a stand against Naktuka's problems. As an example namely the resolution of the Fatu Sinai conflict between Indonesia and Timor Leste in the middle in 2003. Both governments strongly prioritized political and diplomatic lobbies.The final settlement model is not the form of cultural diplomacy with war. The main thing that is of concern to the academic community and society as a cultural social integrity is about efforts to solve it with cultural approach. However, in an academic perspective, the academic community certainly is will use glasses that are different from the general public with use political glasses as a solution. For example, the academic world will use study of scientific studies both qualitatively and quantitatively and through studies research through literature and research in the field with processes proper observation to find a way or resolution for the political conflict in on. Border area disputes essentially have strategic potential towards various aspects of national and state life. Potential and influences this strategic will create political polarization between two countries positively and negative. The aspects in question are aspects of special foreign policy regarding the settlement of the Naktuka case, as well as security aspects for the people in the area border to the two countries so as to create 
harmony in the community at the border Naktuka. Conflict polarization in Naktuka will certainly decorate our discourse to do scientific studies, formulating political policies that can accommodate aspirations the people of both countries and look back or refer back to the agreements pre-existing so that it can be used as a guideline for political settlement as a model. The Naktuka border conflict is a fairly long political process continues to this day. The border is a tangible manifestation of sovereignty (sovereignty) of one country. Because this boundary as sovereignty is the solution Peaceful settlement is the right alternative. Sovereignty will have an impact on political aspects, cultural aspects, economic aspects, social aspects and defense aspects security. Sovereignty or sovereignty must also be based on the awareness of each party to respect each other and uphold the values of nationalism and state sovereignty. In general, East Timor is directly adjacent to two countries, namely Australia with Indonesia. With Australia, the borders of the territory of East Timor include sea boundaries and air. But the most unique thing is the border between Indonesia and Timor Leste, namely the border of the sea, air and land. Especially for the border of the Enclave region (Oecusse), which is an autonomous region belonging to Timor Leste; the enclave area is enclave, which entered the Unitary State of the Republic of Indonesia. This region surrounded by Kupang in the west, TTU in the north and Atambua in the east. This is a uniqueness that is a step in modern countries today, such as which happened before in the political configuration of European countries in the agreement the very famous namely the Westphalia 1648 agreement between England, France, the Netherlands, Germany and others. The Naktuka area conflicts are not only the responsibility of the government both countries, but are a shared responsibility of all elements of society. It is true that the responsibility of the state is to guarantee security, prosperity, justice and improvement of the people's economy. But the community is also required to support each government programs include security issues, order, so that conflicts can overcome and controlled. This means that in the process of finding a way for conflict resolution The public should be involved in dialogue so that it makes it easier for the government both countries to equate perceptions of the problems mentioned above so that the negotiation process or negotiations and diplomas will take place welland satisfying. Naktuka border conflict as a political conflict between two neighboring countries, namely Indonesia and Timor Leste, then of course the resolution of this conflict may not only be using political approaches and political reviews but more important things is the cultural aspect in the two communities will be an important key success. Basically political conflict is caused by two things, as said by Conn, (2001: 31) that political conflict includes horizontal plurality and vertical plurality. The community is included in cultural pluralism, such as religion, race, Languages and others are included in horizontal plurality, while pluralism vertical is a structure of society that is polarized according to wealth, knowledge and power. Approaches that certainly cannot be forgotten so that they can be used as an alternative solution, the author uses two approaches namely political approach and socio-cultural approach. In the political approach, the writers see that the community must be approached politically. While in the frameworksocio-cultural, the authors see that the role of traditional leaders or indigenous people plays an important role in the conflict and its resolution. In using a cultural approach it is considered as an alternative to solve the border problem in Naktuka. Political approach as amethod, both Indonesia and Timor Leste must develop a framework the same, dialogue and compromise so that both parties will feel or benefit from the conflict. This, according to what Conn (2001: 15-20) said, that conflict situations are basically divided into win-lose conflicts (Zero-Sum Conflict) and non-zero-sum conflict. Because of border problems Naktuka is a conflict involving the interests of the state in this matter related to the sovereignty of each country then the most appropriate choice are parties to the dispute, namely between Indonesia and Timor Leste, of course they must sitting together in dialogue, working together and willing to compromise for the sake of interest national state as a sovereignty that cannot be contested. Then the concept the offered non-zero-sum conflict conflict is considered as a model the right way to resolve the Naktuka border conflict. On the basis of the problems mentioned above, the author has the desire toconduct research on this thesis with the title "Alternative Sharing Policy Resolving Naktuka Border Problems between the Governments of Indonesia and Timor Leste Viewed from Cultural Aspects ".

\section{The statement of the problem}

Departing from the background of the problem described above, the writerformulate research problems as follows:

1. What are the alternative policies taken by the Timor Leste government in resolve the Naktuka border conflict between Indonesia and the government Timor Leste?

2. What factors are hindering the settlement of the Naktuka border conflict between the Republic of Indonesia government and the RDTL government? 


\section{Objectives and Benefits of Research \\ Research purposes}

This research aims to:

1. Knowing the dynamics of the history of the ambeno kingdom and Amfoan since the pre-colonial era until the formation of the NKRI.

2. Knowing the dynamics that occur in the Naktuka border area between the government NKRI with the RDTL government.

3. To find out alternative policies taken by the RDTL government in resolve the Naktuka border conflict with the NKRI government.

4. To understand the inhibiting factors in resolving border conflictsNaktuka between the Republic of Indonesia government and the RDTL government.

\section{Benefits}

1. The results of this study are expected to be a reference for conflict resolution unresolved border between the government of NKRI and RDTL seen from the cultural aspect.

2. The results of this study can also be useful as additional references for people who want to know the history of Amfoan in relation to other kingdoms, especially with the Ambenu kingdom.

\section{The Concept of the Borders of a Country}

The border region between countries plays an important role in maintaining state sovereignty. Where sovereignty includes issues, namely authority, population and territory (Howland \& White, 2009: 2). In terms of territory, the border region is real manifestation of a country's sovereignty (Moeldoko, 2013). This is due to because the geospatial region is a boundary with other countries. Besides that, the important role of the border region towards sovereignty is also related to the population has positive potential as well as negative potential. From the positive side thatcitizens of national borders can be used as guardians of sovereignty when needed they can be fulfilled by the state. Whereas from the negative aspects of the population in the region borders may be a threat to the sovereignty of the country when it needs they are not accommodated by the state, but their lives depend on the country neighbor. Threats to state sovereignty can arise due to weak state control on various aspects of life covering the fields of ideology, politics, economics, social culture, defense and security. Anthony Black at the beginning of the middle Ages argued that sovereignty refers to independence / freedom from all kinds of coercion / restrictions formal comes from outside forces (Vincent, 2015: 15). In the context of the country, sovereignty is an absolute force, characterized by the following characteristics which are continuous continuously, without being able to be divided and diverted, and not alienated (Viencent, 2012: $17 \mathrm{http}$ : // pustkailmuhukum. blogspot .com / p / kedaualatan-Ilmu-negara.html). Sovereignty is the highest power owned by the state to make rules of the game (rule of the game) which is permanent and not shared in all regions of the country since birth (MitaNoveria\&Firman Noor. 2017: 9). The concept of the border according to the Political-LIPI Research Center (Noor, 2013), refers to imaginary lines that mark a boundary taken by a political decisions, involving two or more countries, are contained in an agreement legally written acknowledged by parties that agree in it. Within that limit contained strongly that the border is no longer the same as the frontiers which constitute zone of influence which is often agreed upon in a personal, primordial, or mystical, regardless of the legal-political aspect.

\section{Interstate Border Problems}

The most common border problems between countries are highlighted or often appears is about the arrangement and arrangements of border areas in order eliminate various conflicts that occur on borders between countries, (Wila, 2006). Thing this also happened at the border between NKRI - RDTL concerning regulation and governance border management so far. This is not independent and is also related to the agreement in the colonial period such as the Colonial Boundary Treaty between The Netherlands and Portugal April 20, 1859, Convention between The Netherlands and Portugal Relativo to Commerce, Navigation, Boundaries and Mutual Right of Pre-emption in the Timor and Solor Archipelago. In addition, border disputes between Indonesia and Timor Leste are on Naktuka caused by claims for agricultural land, as well as development.

\section{A Country's Policy in Resolving Border}

Discussing the problems of managing border security between Indonesia and Timor Leste, especially East Nusa Tenggara (NTT) with Timor Leste, so things are necessary first seen in general is the legal provisions governing the territory country. In general a provision in Article 1 of Law Number 43 of 2008 confirms that: 
1. The territory of the Unitary State of the Republic of Indonesia, hereinafter referred to with the territory of the country, is one of the elements of the country which is one unity of land area, inland waters, island waters and the sea

2. Territories along with the seabed and the land beneath them, and air space at on it, including all the sources of wealth contained in it.

3. Waters are inland waters, archipelagic waters and the sea territorial.

4. Jurisdictional Area is an area outside the territory of the country consisting of Exclusive Economic Zone, Continental Shelf and Additional Zone where the state has certain sovereign rights and other authorities as well regulated in legislation and international law.

5. State Territory boundaries are boundaries which are separators the sovereignty of a country based on international law.

6. Jurisdictional boundaries are boundaries which are rights separators sovereign and certain authority owned by the state based on statutory and legal provisions international.

7. The Border Area is part of the territory of the country located on the side within the borders of Indonesia with other countries, in terms of limits the territory of the country on land the border area is in the sub-district.

8. Indonesia's Additional Zone is a zone whose width does not exceed 24 (two ninety four) nautical miles measured from the base of the width of the sea territorial measured.

9. The Indonesian Exclusive Economic Zone is an area outside and side by side with Indonesian territorial sea as referred to in laws governing Indonesian waters with limits outermost 200 (two hundred) nautical miles from the baseline where the width of the sea territorial measured.

10. The Indonesian Continental Shelf covers the sea floor and the land below it from areas below sea level located outside the territorial sea, along natural continuation of land area to the outer edge of the continental shelf, or up to a distance of 200 (two hundred) nautical miles from the baseline from which the width of the territorial sea is measured, in terms of the outer edge of the continental edge not reach that distance, up to 350 miles (three hundred and fifty) miles away the sea reaches a distance of 100 (one hundred) nautical miles from the depth line of 2,500 (two thousand five hundred) meters.

11. International agreements are agreements in certain forms and names regulated in International law made in writing as well raises rights and obligations in the field of public law.

12. The Management Agency is a body authorized by law this is in the field of management of State and Border Areas.

13. The Central Government, hereinafter referred to as the Government, is the President Republic of Indonesia which holds the power of state government Republic of Indonesia as referred to in the Constitution State of the Republic of Indonesia in 1945.

14. Regional Governments are governors, regents or mayors, and devices region as an element of regional government administrators. As for the Timor Leste side, the problem of resolving problems the border rests on the RDTL Constitution in article 4 concerning the territory; that then stated in article 3 of the article as follows: The RDTL area covers land area, maritime zone and restricted airspace by national boundaries, which historically cover the eastern part of the island Timor, the OecusseAmbeno enclave along with the islands of Atauro and Jaco. The $\neg$ law defines and defines the territorial waters and territories, EEZ and East Timorese rights to the seabed which borders with countries neighbors and continental runways. States will not release any part of Timor Leste's territory or rights $\neg$ sovereignty over it, without reducing the importance of straightening boundaries. This reality prompted the two countries to form a joint committee has the authority to control the boundaries of the Unitary State of the Republic Indonesia and the Democratic Republic of Timor Leste, where at the central level are regulated through Joint Border Committee (JBC) and Border Liasion Committee (BLC) at the provincial level.

Physically in contact with and supported by (a surface).on the table was a water jug forming a distinctive or marked part of (the surface of something). a scratch on her arm having (the thing mentioned) as a topic. a book on careers as a member of (a committee, jury, or other body). they would be allowed to serve on committees having (the thing mentioned) as a target, aim, or focus. five air raids on the city having (the thing mentioned) as a medium for transmitting or storing information. put your ideas down on paper in the course of (a journey). he was on his way to see his mother indicating the day or part of a day during which an event takes place. reported on September 26 engaged in. His attendant was out on errands regularly taking (a drug or medicine). He is on morphine to relieve the pain paid for by. The drinks are on me added to. a few cents on the electric bill is nothing compared with your security physically in contact with and supported by a surface. Make sure the lid is on indicating continuation of a movement or action. She burbled on (of an entertainment or other event) taking place or being presented. What's on 
at the festival (of an electrical appliance or power supply) functioning. They always left the lights on sinonim: functioning in operation working in use operating denoting subatomic particles or quanta. Neutron denoting molecular units. They were arrested on arrival in Dublin Order what you want from any menu. It's all on the house. Turner, Whistler and Monet ison at Tate Britain until the 15th of May, tickets are £10. This past weekend was my weekend on, so I really couldn't get away from work properly. on the wall keep the lid on The lead singer came on with a huge bottle of wine in one hand and the microphone in the other. it was hanging on the tree put it on the table The priest, to my surprise, launched into a verbal assault on me. He is transfixed by footage of riots showing on Sky News. He answered the door and just had a dressing gown on . I thought you cancelled? Is it on or what? the house on the corner It's getting on . I suppose I'd best get back. She cycled on , through the winding streets of the village to the graveyard beside the old stone church. I got on the bus and went into New York. She felt his hands on her shoulders. Susan was called out of town on business. Ben had to come in and help me put the sheets on . She'll be here later on He flipped through the channels and couldn't find anything good on .

\section{Cultural Approach}

Customary Law according to Van Vollenhoven (Taneko. 1987: 37) known as father of Indonesian customary law, customary law consists of two elements, namely the original law of the population which is generally still not written (non-scriptum juice) and provisions most religious laws have been written (jus scriptum). Whereas according to Soepomo, the definition of customary law as a law that is not written in the regulations legislative (unstatutory law) includes life rules which though not determined by the authorities but adhered to and supported by the people based on principle of conviction, that the regulations have legal force. Cultural values (Williams 1970 in AloLiliweri, 2016: 517), say that cultural values are abstract ideas that implicitly or explicitly share about what is good and right, and what is desired by the community. Cultural values in the form of freedom, prosperity, security which are considered as basic values forming specific norms, and this value must be shared with everyone about what they have to do right in various situations. Then value this shared culture shows the establishment of the role and of the social institutions so that at finally the social institution can answer the social needs of the cultural community in border region.

Border between States in the Realm of Public Administration The state administration system is integrated with various other systems such as politics, economics, social culture, ideology and defense security, in addition with ecosystems such as geography, demography and natural wealth factors. This is a symptom or environmental factors that can affect the administration system. So, that system built must change according to the environment in a community and the administrative area of a country. In a journal written by Hidayat (2011: 15) about the State Border Authority, besides concerning the establishment of the Authority Body that handles aspects of planning, development and supervision of border areas both in economic, social and government, defense and security, the aspects that need to be considered again is the construction of physical infrastructure, enhancing defense capabilities, as well as various economic stimulants of the people. Marnixon (2006: 87) said that the region the border so far only shows backwardness and isolation, so it is necessary there is a new breakthrough with various special policies as the nation's show window. Then most of the border areas of Indonesia and Timor Leste are regions left behind with limited social and economic facilities and infrastructure. as a resultthe border region is not touched by the development program and its people remain in a state of poverty, so that the economy is oriented towards the region neighboring countries. The governments of Indonesia and Timor Leste, of course, are administratively mutual assist and coordinate within the framework of border area administrative cooperation. Communities that are not recorded in the population census, an existence that is difficult to know or even do not have BilheteIdentidade or Identity Card. Business improvement of the administrative system for the people on the borders of the two countries such as population, the use of Pas Lintas Batas is very urgent to do and can an alternative solution. So that the administrative system process in the border simplifies the governments of both countries to identify manual documents as well electronics in the border areas of Indonesia and Timor Leste. Pamudji (2004: 133) Effect of state administration on social factors and culture can be traced through socio-cultural development programs launched by the government implemented by the state administration. US village modernization programs, arts and cultural programs, free education programs, programs realized health or family planning programs and other programs by both countries that are not affordable in the border region. Then of course the government must make a special program for the border region with clear conditions the community is different from non-border. Send input History Saved Community National Boundaries in the Political Sphere Border is an area that is an important position in the order of life state. Interstate borders are imaginary lines that separate regions Indonesia with East Timor which is directly adjacent to land, sea or air. Thus, the border area is a manifestation of configuration of the country with regional sovereignty as understood as the concept of a modern state order based on 
the Westphalia agreement (1648). The determination of the national boundaries is made by a joint institution or team with the procedure systematic. A boundary sign that limits the parts of a region the outermost is controlled by a country (Carlson: 1963). Border or frontier is boundary relations between two neighboring countries (Alexander: 1967). Made a boundary or the border is not arbitrary so to determine the boundary line State borders must involve the two neighboring countries together negotiate. Therefore boundaries between two countries have two objectives which is very important namely; internal goals are for regulatory purposes administrative, legal implementation, to help spread the population, exploitation natural resources and defense and security. While for external purposes is to maintain security out and show the integrity of nation sovereignty. Cultural Approach and Local Wisdom Values as Alternative Settlement

According to Lawrence M. Friedman, (Legal Culture and Social Development; Law \& Society, 1996.) that every legal system always contains three components, namely:

1. Strutural component,

2. Substantial component, and

3. Cultural component.

In the three components mentioned above, in general people always assume or what is called a legal system only includes components structural and substantial without considering the existence of cultural components. Need also explained in the description of what is meant by structural components from a legal system created by the legal system with a variety of functions in order to support the operation of the system that is. Whereas the meaning of substantial components is all-encompassing what is the output of the legal system. In this sense including the norm the law, in the form of legislation, doctrine, insofar as it is all used in the process of working the law. As well as cultural or cultural components law or what is called "The Legal Culture" is the whole factor determining the legal system gets its logical place in the framework culture belonging to the general public. So what is called the legal culture is no other than the overall attitude towards the community towards the existing value system in society that will determine how the law should apply in society.

Culture in the perspective of cultural studies is a real field of place based on various practices, representations, language and habits of a society certain. Cultures are also a contradictory form of rooted common sense on and contribute to shaping everyday life. Hall (in Antariksa, 2000). The first cultural ritual is the local wisdom is the "Tara Bandu". Kultura Tara bandu is a traditional value that has been inherited by people for generations Timor as a whole. Tara Bandu is a traditional traditional ritual performed by indigenous people towards people who are in conflict with the process take an oath. This ritual is done by killing chickens or pigs then the blood is taken and prayed for, then the meat is divided throughout participant ritual. Usually these traditional leaders break the bones that indicate that the mutually agreed problems have been resolved and whoever violates the process from the band will break or die according toprocession of broken bones. The situation is that culture is in accordance with interviews conducted with the sub-district head of Oesilo as well as one of the traditional leaders in Oecusse who revealed that in the territory of the authority which borders on Standing a ritual has been carried out Tara Bandu is between two residents of the border community, so the TTU border with Napan has never had any conflicts. The second local wisdom is a combination of traditional Tara Bandu values with religious value namely Cruz Jovem (cross of youth). Cruz Jovem is a religious activity carried out by the Catholic Church in Timor Leste, by going on a traveling trip the entire territory of the country of Timor Leste for one year is continuously only with on foot. The combination of these two traditions, namely customary values with religious values is a very effective alternative in dealing with various conflicts between organizations youth in Timor Leste. The ritual activity aims to unite the people young man who was involved in a martial arts organization that had been going on since there was a 2006 crisis in Timor Leste. The positive side of these activities can be seen with reappointment of traditional or as agents of conflict resolution by cultural values indigenous peoples and churches. The third third local cultural value which is an alternative approach is NaheBiti Boot. This custom has three syllables, namely Nahe which means title, Biti meaning mat and boot which means big. NaheBiti Boot (deliberation consensus) is an indigenous tradition of Timorese in resolving various conflicts by sitting down together to carry out dialogue so that the end of the agreement is reached custom. Usually done where customary people sit on mats crossed with legs while eating betel nut to talk about traditional problems such as marriage, death, or other problems including conflict. Usually it will be closed by drinking wine or coffee which means an agreement has been made. According to Lloyd (1993), social structure understanding means understanding roles, interaction between roles, rules and culture. Social structure in structuralist methodology very loose. Lloyd calls it loosely structured, social structure determinism does not cover the entire community. this social structure in general Send input History Saved Community. 


\section{Factors inhibiting natural conflict resolution}

Settlement of the Naktuka conflict between the governments of Indonesia and Timor Leste at this time facing a number of small problems which are obstacles for the two countries. That matter can be seen from several inhibiting factors for both countries to be resolved. Factors the inhibitors are:

1. There are still violations committed by the border community against the determination of the Naktuka region as a free zone.

2. The incomplete determination of the clear boundary between the two countries, namely Timor Leste and Indonesia.

3. The lack of supporting facilities and preachers for officers who are on duty in the region borders, such as UPF, TNI, Immigration, customs and excise for each country.

4. The rise of illegal trade is carried out due to not being as optimal as controls a result of the lack of human resources at the border.

5. There is dissatisfaction with the Oecusse and Amfoang people because of factors political.

6. There are still administrative violations in the border region supported by authorized officials. The factors mentioned above are inhibiting factors that need to be overcome so that can encourage the settlement of border issues between Indonesia and Timor Leste. The above constraints can certainly be overcome or even other factors

can

become

inhibitor.

\section{Conclusion}

Based on all the results of the discussion above, it can be concluded that: The Amfoang community and the Ambeno community have the same cultural roots. Both have the same language, the same physical characteristics, the same religion and both also have the same culture and cultural values and inhabit one politically different regions. The similarity of traditional values with characteristics polite society and thick cultural values, show that it is customary the community of the two countries cannot be separated from each other in a cultural context. Cultural values are local wisdom that needs to be developed by the government as a model of conflict resolution. The conflict that emerged after the independence of East Timor in 1999 was trigger factors for conflict between citizens of the country. Traditionally though not separated, however, politically they are different. Political and ideological differences follow influencing the value of local or customary values and culture. other factors are starting emergence of claims on agricultural land and jealousy or problems other dissatisfaction that helped undermine the atmosphere of cultural relations as a value or the local wisdom mentioned above.

\section{Reference:-}

Books

1. Abubakar, Mustafa. 2006.MenataPulau-Pulau Kecil Perbatasan: BelajardariKasusSipadan, LigitandanSibatik. Jakarta.

2. Anderson, Benedict. 1972.Imagined Communities, Reflections on the Origin and Spread ofNationalism. London and New York: Verso.

3. Budiardjo, Miriam.Dasar-DasarIlmuPolitik. 2003, GramediaPustakaUtama, Jakarta.

4. Brunet, ImanuelJailly, 2005. Theorizing Borders: An Interdisiplinary perspective",Geopolitics.

5. Conn, Paul. Conflict and Decision Making: An Introduction to Political Science. New York:Harper \& Row Publisher

6. Creswell, John W. 2007. Research Design. PendekatanKualitatif, Kuantitatif, dan Mixed.

7. Dahrendorf, Ralf. "Conflict Groups, Group Conflicts, and Social Change,"

8. Deeley, Neil. "International Boundaries of East Timor", dalam Boundaries and TeritorryBriefing.

9. Dunn, William N. 2000. Public Policy Analysis: An Introduction, Prentice HallInternational, Englewood, New Jersey.

10. Dye, R. Thomas, 1976. What Governments, Why They Do It, What Difference It Makes.

11. Tuscaloosa, University of Alabama Press.

12. Hidayat A, Atep. 2011. BadanOtoritaPerbatasan Negara.

13. Holsty, K.J. 1985. PolitikInternasional: SuatuKerangkaAnalisis

14. Ikbar, Yanuar. Metodologi\&TeoriHubunganInternasional. RefikaAditama, Bandung.

15. Indihono, Dwiyanto. 2017. KebijakanPublikBerbasis: DYNAMIC POLICY ANALYSIS, GavaMedia, edisi 2 revisi. 
16. Nainggolan, PoltakPartogi. PermasalahanPerbatasan Indonesia dengan Negara-NegaraTetangga Lain: UrgensinyaBagiSebuahPenelitian". Tim Peneliti.

17. Nasikun. 1974. SebuahPendekatanuntukMempelajariSistemSosial Indonesia.Jogyakarta: FakultasSospol UGM.

18. Nor, Firman, 2017. Negara danKedaulatanPolitik: EvaluasiAtasPemeliharaan RasaKebangsaanOleh Negara.

19. Noveria, Mita\&Firman Noor, 2017. Kedaulatan Indonesia Di WilaahPerbatasan. YayasanPustakaObor Indonesia, LIPI.

20. Pruitt, Dean G. dan Jeffrey Z. Robin, 2004. TeoriKonflikSosial. Yogyakarta: PustakaPelajar.

21. Rosdiana, H.A. 2015. ManajemanKonflik, Bandung.

22. Sarwono, Sarlito W. 1999. PengantarUmumPsikologi. Jakarta: BulanBintang. Hlm. 145

23. Surbakti, Ramlan. 2010. MemahamillmuPolitik. "Konflikdan Proses Politik". Jakarta.

24. Soeprapto, (1996: 54) Cita Negara Persatuan Indonesia.

25. Wila, Marnixon.2006.Konsepsi HukumDalamPengaturandanPengelolaan WilayahPerbatasanAntarnegara. Bandung.

26. Wuryandari, Ganewati. 2017. PengelolaanKedaulatan Negara DalamKonteksPertahananDi Perbatasan RI Malaysia.

27. Wuryandari, Ganewatidkk, 2009. Keamanan Di Perbatasan Indonesia - Timor Leste:SumberAncaman Dan KebijakanPengelolaannya. PustakaPelajar. 